\title{
Towards a Sustainable and Efficient Use of Manure in Agriculture: The Dutch Case
}

\author{
FRANK J. DIETZ \\ Department of Public Administration, Erasmus University, P.O. Box 1738, 3000 DR Rotterdam, \\ The Netherlands. \\ and \\ NICO J. P. HOOGERVORST \\ Environmental Forecasting Office, National Institute of Public Health and \\ Environmental Protection, P.O. Box 1,3720 BA Bilthoven, The Netherlands.
}

\begin{abstract}
Rapid increases in livestock production in the Netherlands have changed manure from a valuable input into a mere waste product. This is especially true for the southern and eastern parts of the country, where specialized pig and poultry farms have concentrated on sandy soils. As these farms generally own very little land, they largely depend on imported feedstuffs. As a consequence, manure is applied to the land in such large quantities that serious environmental problems have resulted: (1) eutrophication of surface water by phosphate emissions; (2) pollution of groundwater by nitrate emissions; and (3) acidification by ammonia emissions.

In the last few years the Dutch government has developed a manure policy to counteract these effects. Our analysis of that policy has revealed at least three fundamental defects, which render the manure policy ineffective and inefficient. In this paper proposals are made to remove the defects in current manure policy. Much attention is paid to the problem of designing a mixture of policy instruments which is both effective as well as efficient in limiting the environmental problems caused by manure. It is shown that the use of financial incentives in regulation can substantially improve the efficiency of the manure policy. Finally, the main economic consequences of the proposed policy are examined for the public sector as well as for the agricultural sector.
\end{abstract}

Key words. Manure problem, nutrient policy, nutrient surplus, regulatory levy, sustainability, agriculture, intensive livestock sector, acidification, groundwater pollution, eutrophication.

\section{The Manure Problem in the Netherlands}

Over the past 40 years Dutch agriculture has witnessed an unprecedented development in its livestock production This is most clearly illustrated by the growth of animal numbers (Table I). Between 1950 and 1990, cattle numbers have doubled, the number of chickens has quadrupled and - most dramatically - the number of pigs is almost seven times higher now than in 1950. This development should be understood (cf. Van der Stee et al., 1989 ) as a response to:

1. a growing international demand for animal products;

2. a favorable EC-common agricultural policy, that is:

- government price support for milk,

- no import levy for imported feedstuffs, and

- substantial price support for cereals; 
Table I. Dutch livestock in million heads

\begin{tabular}{llll}
\hline Year & Cattle & Pigs & Poultry \\
\hline 1950 & 2.5 & 1.9 & 23.5 \\
1955 & 3.0 & 2.4 & 30.7 \\
1960 & 3.5 & 3.0 & 42.4 \\
1965 & 3.8 & 3.8 & 42.3 \\
1970 & 4.4 & 5.7 & 55.4 \\
1975 & 5.0 & 7.2 & 68.1 \\
1980 & 5.2 & 10.1 & 81.2 \\
1985 & 5.2 & 12.4 & 89.9 \\
1990 & 4.9 & 13.9 & 92.8 \\
\hline
\end{tabular}

Source: Wijnands, Luesink and Van der Veen, 1988, p. 242; CBS, 1991.

3. an excess labor supply in agriculture, especially in the sandy regions of the country.

Dutch farmers made good use of the harbor neighborhood of Rotterdam. Large amounts of concentrated feedstuffs were imported, enabling the development of a flourishing pig and poultry sector. In the dairy sector, farmers merely combined the guaranteed product prices with climatic advantages and continuously improving production techniques. It was a success story that many EC farmers and ministers were envious of. The growing imports of feedstuffs resulted in an even sharper increase in exports of agricultural products. The only product that was not exported, however, was manure. Understandably, the substantial growth in animal numbers resulted in an equally dramatic growth in volume of that smelly substance.

In the old days animal manure was highly valued for its ability to increase crop production. However, with the invention of chemical fertilizers, and with the segregation of the traditional mixed farms into specialized arable farming and specialized livestock production, manure lost its prominent position. Especially on the specialized pig and poultry farms, manure is now often treated as mere waste, that needs to be disposed of in the cheapest way possible. As these farms generally own very little land, they largely depend on imported feedstuffs. As a consequence, manure is applied to the land in such large quantities that serious environmental problems have resulted.

To illustrate the waste-like character of manure, one could compare the actual application of nutrients with the nutrient requirements for various crops (Table II). The 'overfertilization' is most striking for green maize, a typical crop for pig farms. Whereas the requirements for nitrogen are 
Table II. Estimated use of nitrogen (from manure and chemical fertilizers) in 1985 compared with the nitrogen requirements of various crops $(\mathrm{kg} / \mathrm{ha})$

\begin{tabular}{lrlll}
\hline & Clay & & Sand & \\
\cline { 2 - 5 } & Used & Required & Used & Required \\
\hline Grassland & 530 & 315 & 590 & 350 \\
Green maize & 1135 & 200 & 930 & 200 \\
Arable land & 275 & 160 & 250 & 180 \\
\hline
\end{tabular}

Requirements based on cattle numbers per hectare for grassland and on actual crop mix for arable land.

Source: Calculated from Van Biezen and Hoogervorst, 1989.

approximately 200 kilograms per hectare, the average application easily reaches 900 kilograms per hectare in the sandy soil regions. On grassland nitrogen use is as high as 500 (on clay) to 600 (on sand) kilograms per hectare, which is 30 to 50 percent higher than required.

The environmental problems related to the use of manure can be grouped into three categories: (1) phosphate emissions to surface water, (2) nitrate pollution of groundwater, and (3) acidification by ammonia emissions. ${ }^{1}$ The quality of surface water in the Netherlands has been seriously affected by high phosphate concentrations, resulting in abundant algal growth and distortions of fish populations. Only 30 to 35 percent of the phosphate that farmers apply is taken up by the crops; the remainder is largly absorbed by the soil, which acts as a buffer. At present, only 1 to 3 percent of the applied phosphate reaches the surface water (accounting for roughly $15 \%$ of the yearly phosphorus load). By continuing to fill up this buffering capacity of the soils, we risk a situation in which plant and fish life in Dutch waters will be destroyed forever.

The nitrate pollution of groundwater is primarily perceived as a health problem. Roughly $70 \%$ of our drinking water is produced from groundwater. Moreover, the continuous deterioration of the quality of surface water increases the importance of groundwater as a source for drinking water. Due to high levels of nitrogen use in agriculture, nitrate concentrations in groundwater continue to rise. In some instances wells have had to be closed down, and more close downs are expected.

The third environmental problem is related to acidification. It is commonly known that the acidification problem has a strong trans-boundary component, which makes it very difficult to solve. The production and spreading of manure leads to volatilization of ammonia. Ammonia emissions account for some $60 \%$ of the contribution of the different Dutch source categories to the total deposition (Erisman and Hey, 1991, p. 84). It 
therefore seems most effective for the Netherlands to focus on the reduction of ammonia emissions (instead of $\mathrm{NO}_{\mathrm{x}}$ and $\mathrm{SO}_{2}$ emissions) in order to reduce acid deposition on Dutch territory.

Although these environmental problems occur throughout the country, there are certain regions where the damage is intense. This is due not only to the regional differentiation in agricultural production, but also to the specific characteristics of the environment. Unfortunately, the activities in agriculture that pollute most are located in the most vulnerable regions of the country, that is on the sandy soils in the south and the east (see Figure 1). The sandy soils support the highest concentration of pigs and poultry, which is reflected in the regional concentration of the phosphate production in the intensive livestock sector (see Figure 2).

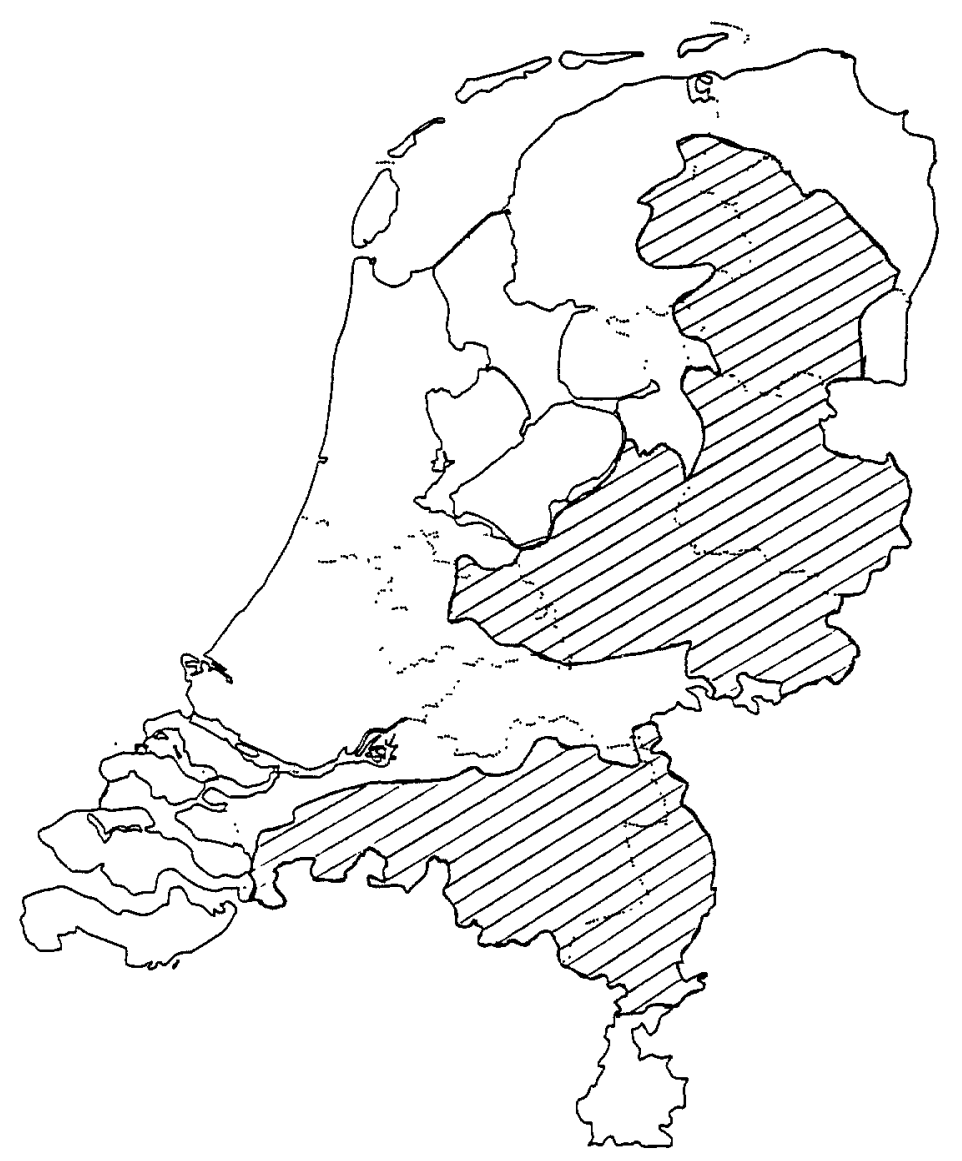

Fig. 1. The location of the sandy soils in the Netherlands. 


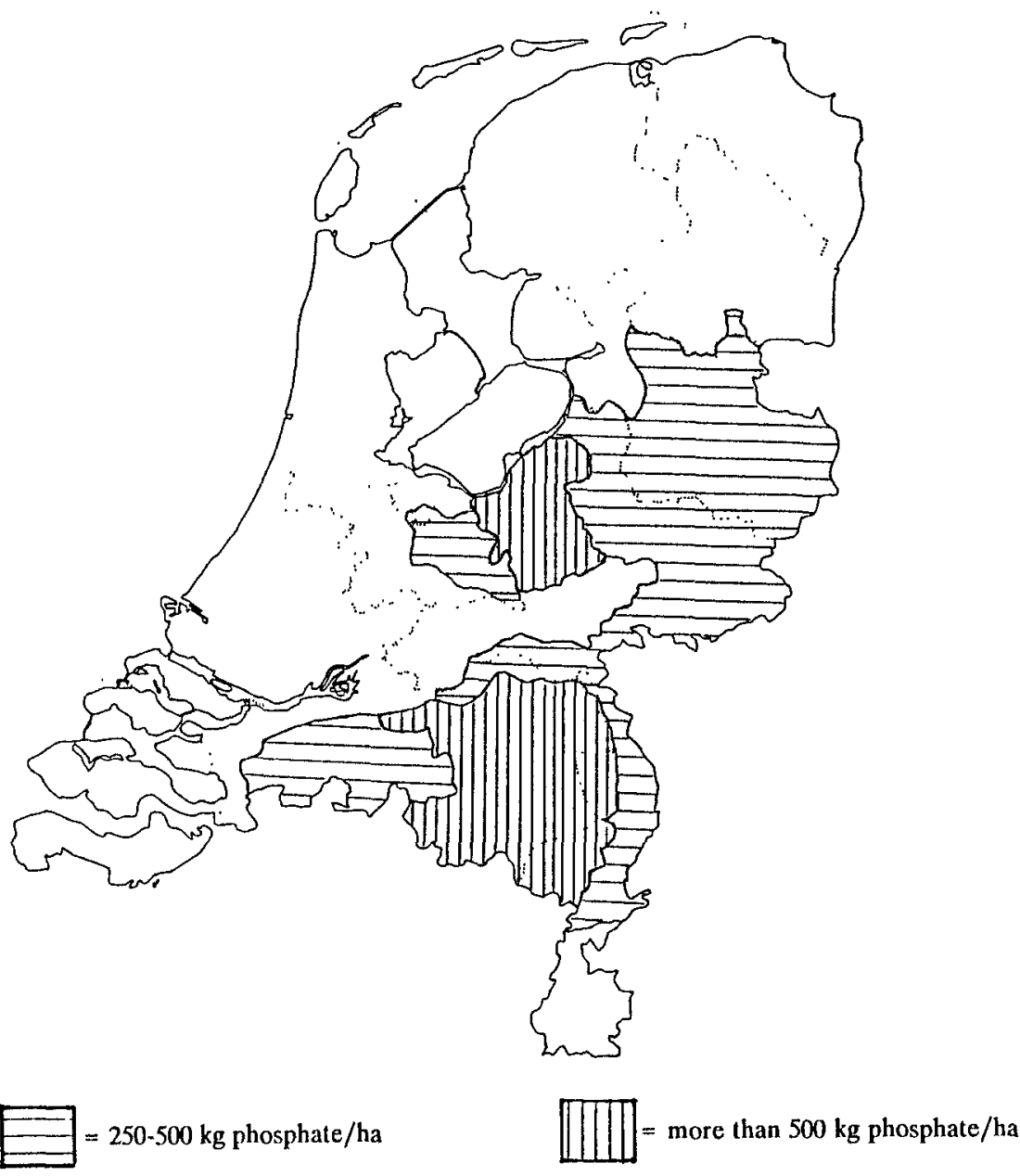

Fig. 2. Phosphate production from livestock above $250 \mathrm{~kg}$ per ha per agniculture area in 1984 (CBS, 1986, p. 22).

Water movements through sandy soils are relatively rapid, which explains why leaching of nutrients to the groundwater occurs most prominently in these regions. The map in Figure 3 shows the areas with the highest concentrations of nitrogen in percolation water. These areas mainly correspond with the location of the sandy soils (Figure 1), as well as the regional concentration of Dutch intensive livestock farms (Figure 2).

Only $7 \%$ of the country is covered with forests. Unfortunately, the sandy soils support by far the greater part of the Dutch forests, which have been shown to be highly sensitive to ammonia concentrations in the air. The map 


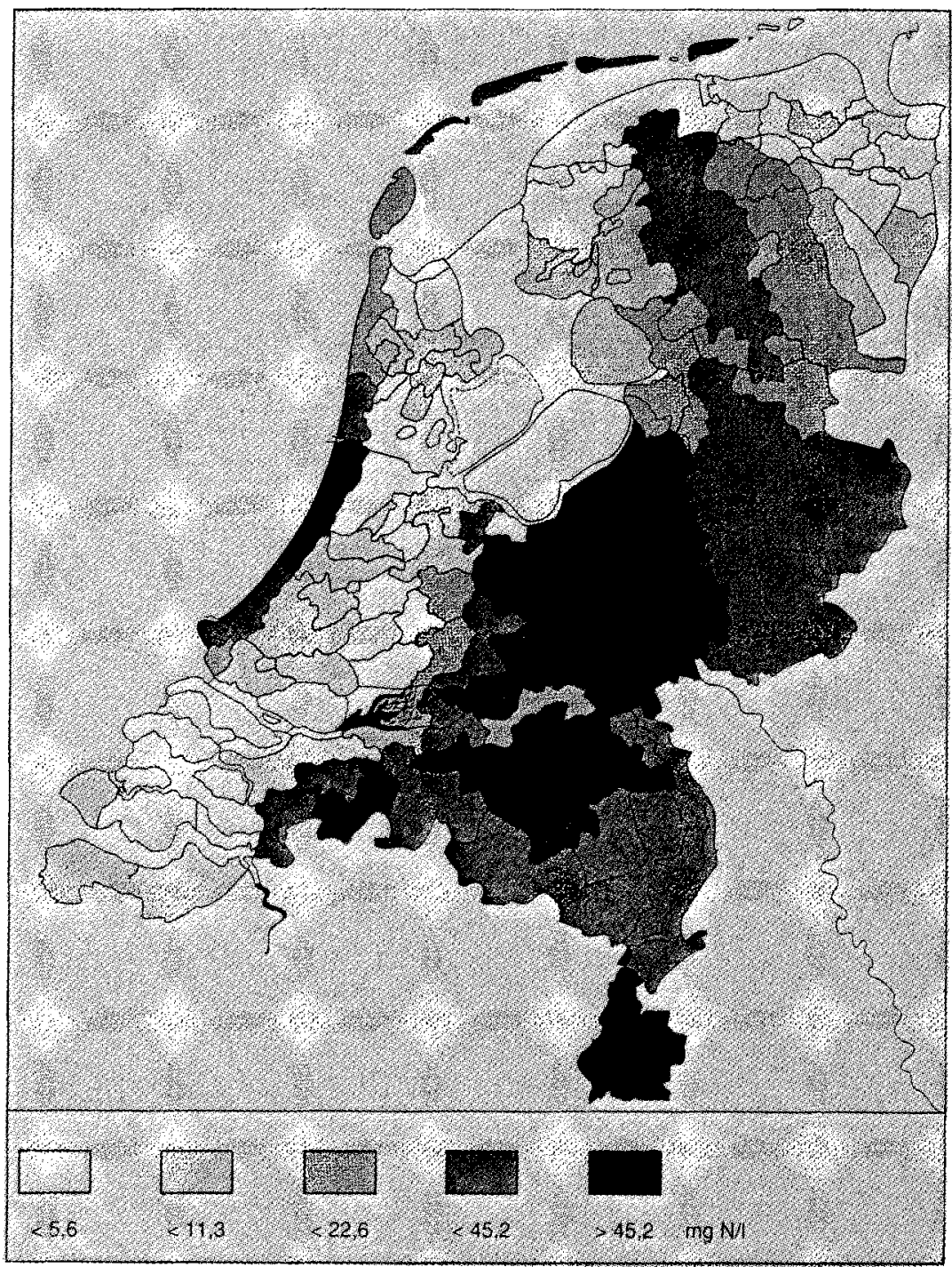

Fig. 3. The average concentration of nitrogen in percolation water per agricultural area (Langeweg, 1988, p. 208).

in Figure 4 shows the deposition of the acidifying substances $\mathrm{NO}_{x}, \mathrm{SO}_{2}$ and $\mathrm{NH}_{\mathrm{x}}$. The map in Figure 5 shows the (calculated) concentration of $\mathrm{NH}_{3}$ in the air. It is clear that there is a significant correlation between the largest load of acidifying depositions, the regions in which most intensive livestock farms are concentrated and the regions in which the greatest part of the Dutch forests are located. Although there is no established monocausal 

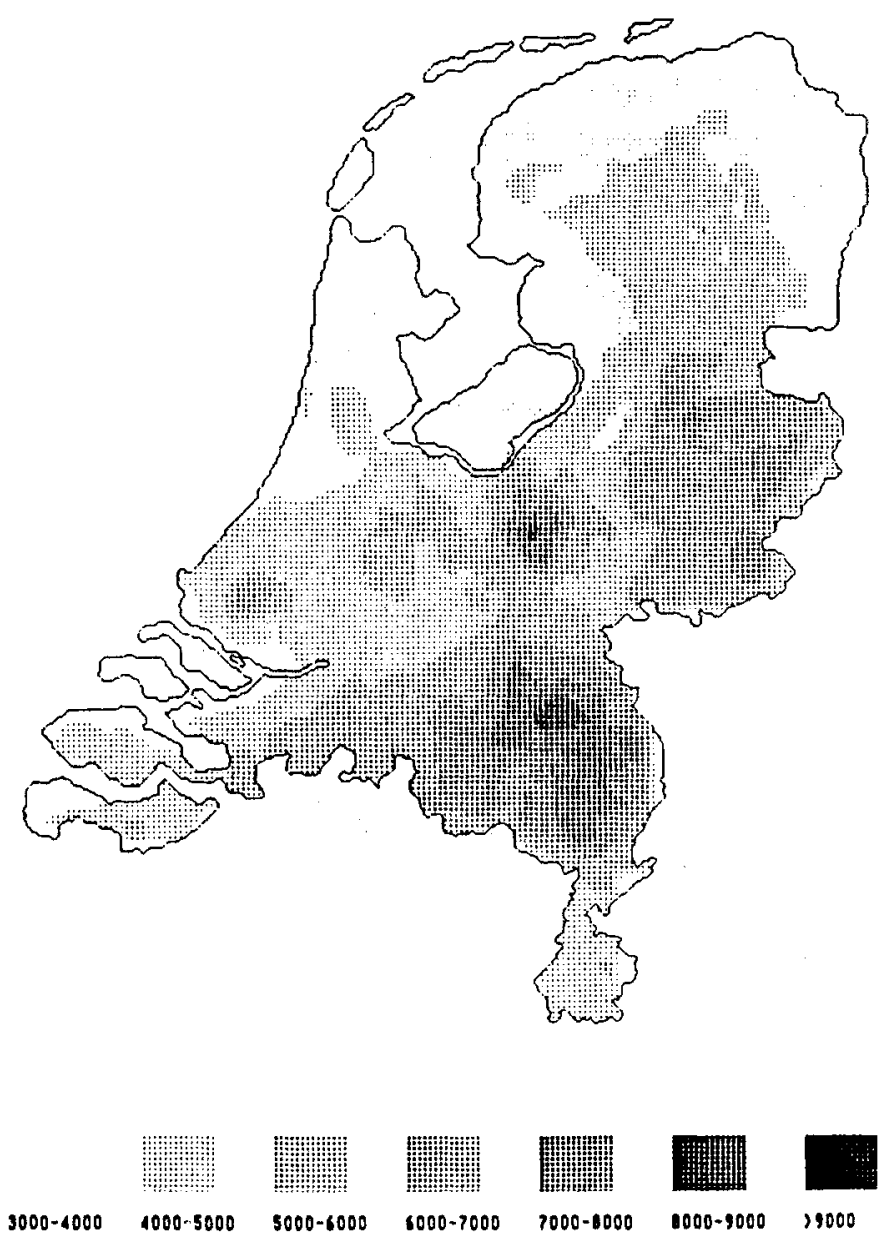

Fig. 4. The deposition of the acidifying substances $\mathrm{NO}_{\mathrm{x}}, \mathrm{SO}_{2}$, and $\mathrm{NH}_{3}$ in the Netherlands. (Heij and Schneider, 1991, p. 71).

relationship between acid load and forest health, "acidifying deposition generally reinforces the impact of traditional stress factors (frost, drought, disease and pests) on forest health" (Heij and Schneider, 1991, p. 11). Some $50 \%$ of all Dutch forests show signs of little to severe damage and some $19 \%$ is seriously threatened (LNV, 1990).

\section{The Manure Policy of the Dutch Government}

In order to curb the adverse environmental effects of the development of the livestock sector, the Dutch government has developed a manure policy. 


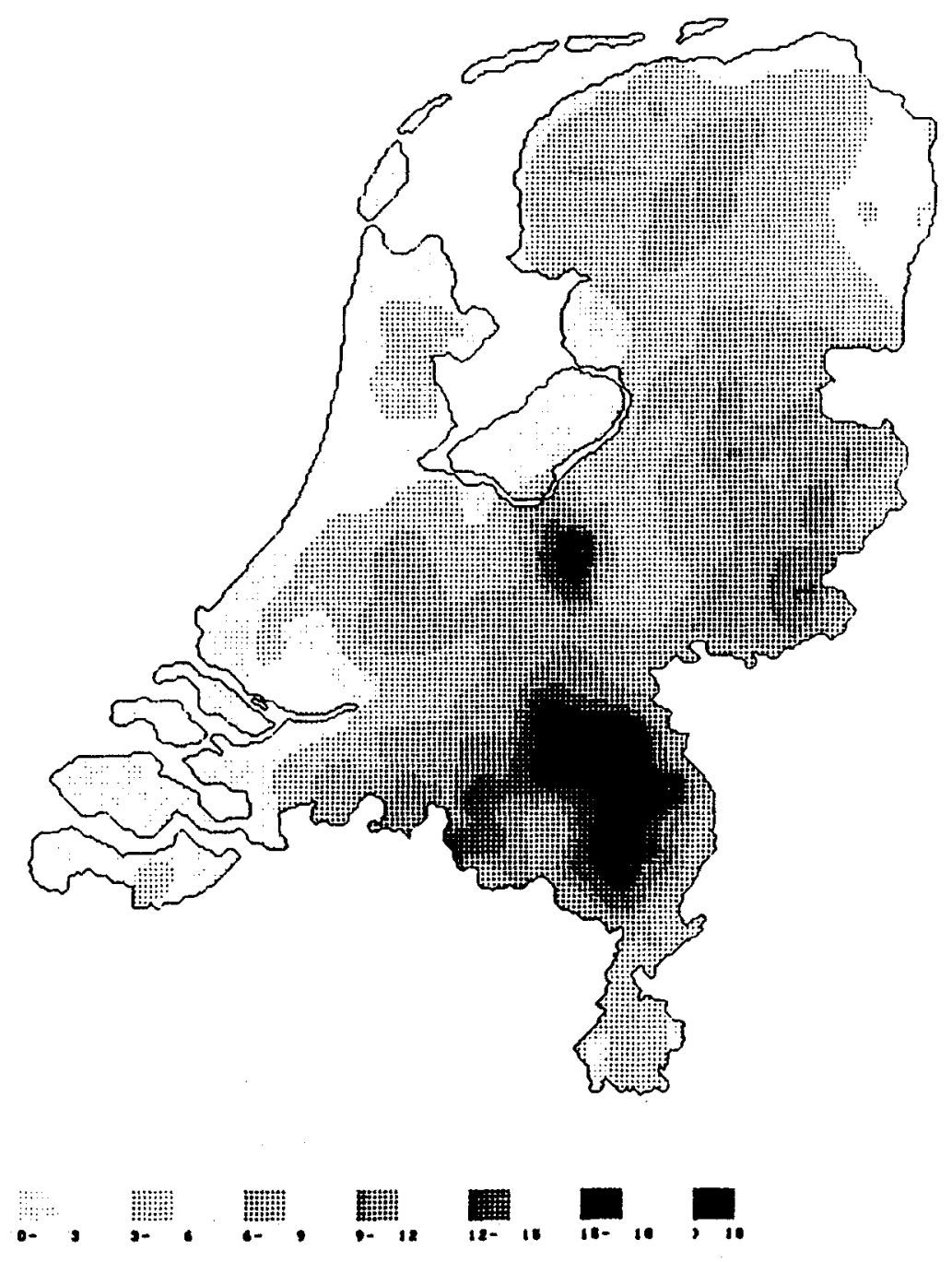

Fig. 5. The calculated concentration of $\mathrm{NH}_{3}$ in the air in the Netherlands (Heij and Schneider, 1991, p. 62).

The policy aims at a gradual reduction in the use of manure on agricultural land, without, and this is important, reducing the size of the national herds. In the government's view farmers should be given enough time to make the necessary adjustments. The manure policy is designed to regulate the application of phosphate contained in manure. It is acknowledged that nitrogen in manure also causes environmental problems, but the volatile nature of this element was thought to cause insurmountable problems in the develop- 
ment of straightforward legislation. It was believed (and probably mostly hoped) that by regulating the use of manure-phosphate, the nitrogen application could also be restricted.

The Interim Act came into force in November 1984. This law was designed to prevent farmers from expanding their herds of chickens and pigs. In May 1987 the government proclaimed so-called phosphate standards. The application of manure was limited to amounts equivalent to 250 $\mathrm{kg}$ phosphate per hectare for grassland, $350 \mathrm{~kg} / \mathrm{ha}$ for green maize and 125 $\mathrm{kg} / \mathrm{ha}$ for all other arable crops (see Table III). These standards will be reduced in four steps until, in the year 2000, the final standards will have been reached. The exact level of the final standards has not been determined yet, but they should be equivalent to the amount of phosphate taken up by the various crops.

The amount of manure that cannot be used on farmland according to the ruling standards, is called the manure excess. The manure excess can be calculated at various levels: farm level, regional level and national level. It all depends on the amount of manure trade actually taking place or presumed to be (theoretically) possible. This has made public discussions on this subject extremely complicated.

A manure excess at farm level is taxed with a (relatively small) charge. This manure excess levy is the main financial source of the so-called Manure Fund. The government has created the Manure Fund to supply financial support for research and technological developments that can help to alleviate the manure problem. All efforts are concentrated along three lines of approach:

1. reducing phosphate (and nitrogen) contents in animal feed;

2. the transportation of excess manure to deficient areas;

3. the development of manure processing plants.

Most of the money and attention has gone to the development of manure processing plants. It is hoped that these factories will turn the watery manure into a dry granular fertilizer that can compete with ordinary

Table III. Legal standards for using manure in $\mathrm{kg}$ phosphate/ha/year

\begin{tabular}{llll}
\hline Period & Grassland & Green Maize & Arable Land \\
\hline $1987-1990$ & 250 & 350 & 125 \\
$1991-1994$ & 200 & $250-150$ & 125 \\
$1995-2000$ & 175 & 125 & 125 \\
2000 and after & amount of phosphate taken up by the crops &
\end{tabular}

Source: Ministerie van Landbouw, 1989, p. 51, and (for green maize) Notitie Mestbeleid Tweede Fase. 
chemical fertilizers. In that way, manure would also be a product that can be exported, which would not only reduce the national manure excess and add to our balance of payments, but also fits in very well with "Dutch tradesmanship".

\section{Main Points of Criticism}

The preceding description of the Dutch manure policy could only sketch out the main elements; we simply lack space here to go into it in greater detail. It contains enough information, however, to bring the following three points into critical perspective. The criticisms imply that we tend to differ from the government in our views on the relative values of farm incomes and environmental quality.

The first shortcoming of the present manure policy relates to the range of regulated substances. The nitrogen problem cannot be resolved by a phosphate policy. Besides, a phosphate policy can only be effective when it aims to regulate all phosphate flows, not only the flows contained in manure originating from cows, pigs and chickens. Up till now the use of chemical fertilizers has been completely free from any form of regulation as well as the use of manure from sheep, goats, horses, fur-producing animals, etc.

The second, more fundamental criticism relates to the focal point of the legislation. At present it is mainly developed to regulate the production of manure. Unintentionally, the farmers have effectively obtained so-called manure quotas, which have developed into manure production rights. At this moment these production rights are not tradeable, but considerable political pressure is being exerted to change this. The environmental problems, however, are not directly related to the production of manure, but to its application (methods and quantities) which determines the emission of certain components into the environment. This implies that transportation. of manure to deficient regions should be treated as a long-term solution instead of a temporary one and should not be subjected to a surplus levy. It also implies that manure quotas could simply be rendered superfluous, which could substantially add to the transparency of the regulations and could give farmers more freedom in adapting their production process.

The third point of criticism relates to the choice of policy instruments. The current manure policy is dominated by action prescriptions (such as manure ploughing, phosphate standards and manure accountancy). Insofar as charges are imposed, they are meant to finance adjustments at farm level (like subsidies on manure storage facilities) and research (such as pilot plants for manure processing and the development of animal feed containing less phosphorus). However, the current charges (like the manure excess levy) are too low to expect any inducements in emission-reducing behavior of farmers. An excellent chance has here been missed to use financial 
incentives as a policy instrument. With a package of well-chosen levies and subsidies, farmers could be continuously stimulated to minimize leakages of nutrients to the environment.

In the following sections proposals are made to remove such shortcomings in current manure policy. Most attention will be paid to the question of which mixture of policy instruments will be effective, as well as efficient, in limiting the leakages of nutrients to the environment. The use of financial incentives in regulation could, in our view, substantially improve the efficiency of the manure policy.

\section{Manuring Standards}

The policy we propose in this paper to limit the nutrient leakages from agriculture, contains standards for phosphate and nitrogen application. These environmental standards for both nutrients, as specified in Table IV, should be attained by the year 2000 . This can be realized by a yearly (step by step) reduction of the ruling standards, starting form present application rates.

The environmental standards for phosphate are relatively easy to establish. They can be set equal to the uptake of phosphate by agricultural crops. This reflects the notion that the accumulation of phosphate in soils is undesirable. It also reflects the knowledge that applied phosphate remains available to agricultural crops; losses over time are relatively low.

For nitrogen the situation is different. In addition to uptake by crops, applied nitrogen disappears from the topsoil through volatilization, denitrification, immobilization and leaching to groundwater. In modern farming the application of nitrogen therefore needs to exceed its uptake by crops. The difference between application and uptake should be kept to a minimum in order to prevent environmental degradation. Since fertilizers are relatively cheap, farmers (and researchers) have not put much effort into minimizing this difference. Consequently, the government (examining the possibilities for legislation to curb nitrogen losses from agriculture) found

Table IV. Environmental standards for the use of phosphate and nitrogen

\begin{tabular}{llll}
\hline & Grassland & Arable land* & Green maize* $^{*}$ \\
\hline Phosphate $\left(\mathrm{kg} \mathrm{P}_{2} \mathrm{O}_{5} / \mathrm{ha}\right)$ & 110 & 70 & 75 \\
Nitrogen $(\mathrm{kg} \mathrm{N} / \mathrm{ha})$ & & & \\
- clay soil & 350 & 235 & 235 \\
- sandy sol & 330 & 130 & 130 \\
\hline
\end{tabular}

* Including mandatory soil coverage by crops during the winter season.

Source: Hoogervorst et al., 1989, p. 24. 
insufficient practical or scientific grounds for the development of standards for nitrogen application. Apparently they feared the threat of possible reductions in crop yields more than the certain consequences of continued nitrate leaching to the groundwater. Officially they sought to curb nitrogen leaching by regulating the application of manure on the basis of its phosphate content. In light of the present environmental problems a different approach seems to be warranted. We have interpreted existing information in order to develop preliminary application standards for nitrogen. These (environmental) standards should be imposed by the government and adjusted when further scientific research provides sufficient evidence for adjustments. Studies in the Netherlands (see Neeteson, 1989; Meyer and Lalkens, 1988; see also Table II) suggest that substantial reductions in nitrogen application can be acheived with little or no reductions in crop yields.

In order to develop standards for nitrogen application, information is needed on (1) the environmentally acceptable level of ammonia volatilization and nitrate leaching and (2) the relationships between nitrogen application and volatilization/leaching. Present environmental experience suggest that ammonia losses should be reduced by 90 percent and that leaching of nitrate should be limited to $25 \mathrm{mg}$ per litre ${ }^{2}$ (Langeweg, 1988). This implies that volatilization should be limited to $6 \mathrm{~kg} \mathrm{NH}_{3}$ per hectare of arable land, to $15 \mathrm{~kg} \mathrm{NH}_{3}$ per hectare of grassland in afforested areas, and to $35 \mathrm{~kg} \mathrm{NH}$ per hectare of grassland in other areas. For nitrate leaching there is a limit of $34 \mathrm{~kg}$ nitrogen per hectare of agricultural land. The relationship between (allowable) nitrate leaching and corresponding nitrogen application is taken from Kolenbrander (1981) and distinguishes between crops (grassland vs. arable crops) and soil types (sand vs. clay). This simplified approach does not take account of differences in ground water level, and other complicating factors. This is a practical choice rather than a fundamental one. Each policy has to find a balance between practicability and equity. In order to combine an agriculturally acceptable nitrogen application rate with an environmentally acceptable level of nitrate leaching, it seems necessary to prescribe crop coverage of the soil during the winter season. The environmental standards for nitrogen (see Table IV) are then derived by adding the allowable nitrogen volatilization to the application levels derived from the Kolenbrander relations. In this way, the reduction of all nitrogen losses from agriculture are covered by one standard. ${ }^{3}$ Farmers are free to choose between chemical fertilizer and manure, as long as they meet the environmental standard. This is believed to stimulate farmers to apply manure in such a way that nitrogen volatilization is kept to a minimum. Where this stimulus proves to be insufficient to reduce ammonia emissions, additional prescriptions of application methods could be considered.

It is scarcely possible to compare the environmental standards in Table 
IV with the final standards the government is aiming for. This is due to two circumstances. First, the government has not (yet) developed final standards for the use of nitrogen. Second, the government has remained rather vague about the precise level of the phosphate standard that ultimately has to be attained by the year 2000 .

\section{A New Surplus Levy}

The current manure excess levy has been set at a relatively low level. ${ }^{4}$ Discussions on the level of this levy were dominated by static and financial considerations. A low levy was thought to yield sufficient funds for manure policy support. Moreover, a number of farmers would be confronted with transportation costs for excess manure. These costs range from 6-25 guilders per ton of manure, which, for instance, easily consumes $50 \%$ of the net income per fattened pig. Since agrieultural policy also aims to support farmers' income, it was thought to be undesirable to impose an additional, relatively high excess levy.

The economic implications of this choice have received only little attention. To explain these implications, we constructed Figure 6, showing the

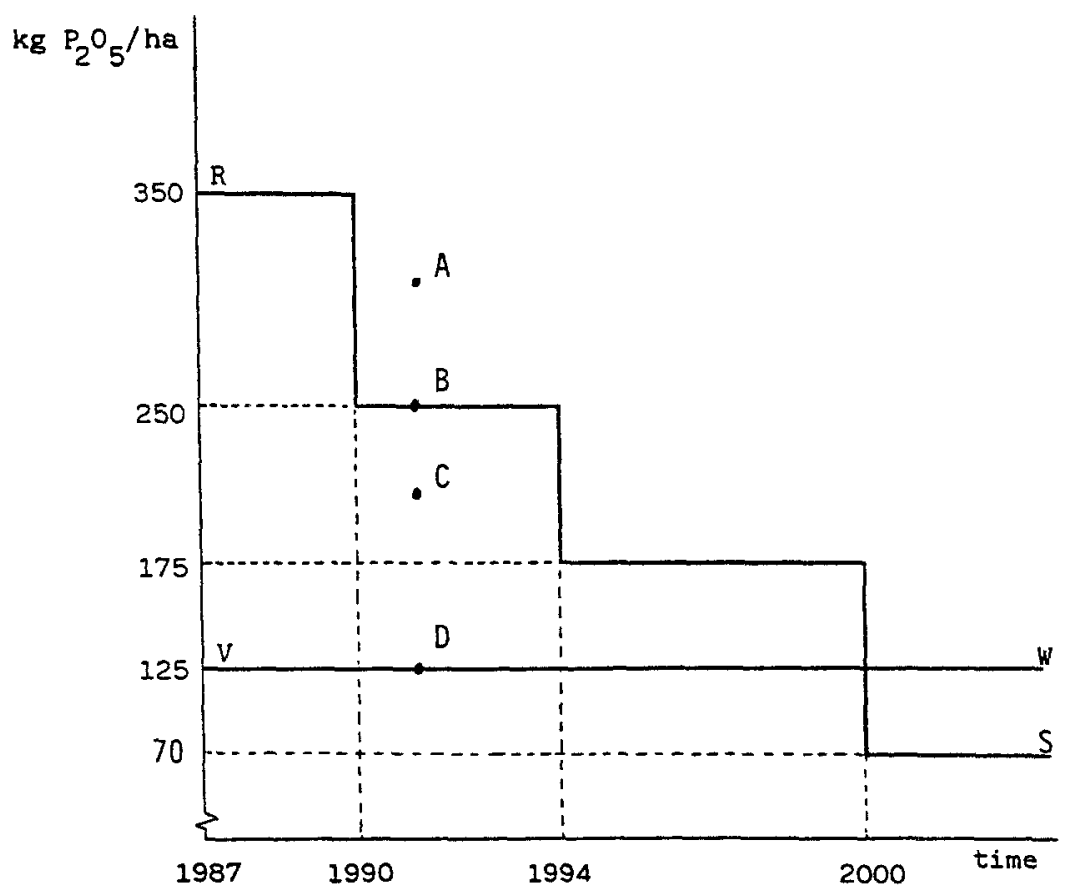

Fig. 6. The development over time of the legally allowed manure-phosphate production of a farm per hectare of green maize. 
example of green maize. The figure charts the development over time of the legally allowed phosphate production in manure per hectare of a farm growing only green maize. The line RS shows that the ruling standards for green maize will be decreased in three steps from $350 \mathrm{~kg}$ phosphate per hectare to the probable final standard of $70 \mathrm{~kg}$ phosphate per hectare (our assumption). Similar lines can be drawn for grassland and arable crops. The line VW represents the level of $125 \mathrm{~kg}$ phosphate per hectare which is presently used as a franchise level for the calculation of the excess levy.

Let us assume that Farm A produces a manure excess in 1991. Consequently, this farm is legally forced to transport the quantity $A B$ off its premises. At the same time Farm A pays an excess levy for the quantity $\mathrm{AD}$. Note that the term 'excess' is used with two different meanings, which adds to the confusion over the manure policy. In order to avoid costs, Farm $\mathrm{A}$ will compare the costs of transporting quantity $\mathrm{AB}$ with the costs of reducing the phosphate production by the same amount (either by switching to low phosphorus feeds or by adapting the size or composition of the herds). The use of chemical phosphate fertilizer is not yet affected by this regulation (although the government has announced that after 1995 it will be). Within the given cost structure it is highly unlikely that Farm A will reduce its manure-phosphate use any further than to the line RS. This means that the speed at which the final standards are reached is largely determined by the shape of line RS. A farm that finds itself under this line (like Farm C) is likely to continue its present farming practices (feeding, fertilization) until a new and stricter standard comes into force. Most dairy farms are in such a position. This implies that since 1984 (when the first manure legislation was issued) valuable time has been lost in providing these farmers with an incentive to reach final standards as soon as possible. A higher excess levy, possibly combined with subsidies on manure transportation costs, could have had this incentive effect. Thus, from an environmental point of view, the government excess levy should be revised.

To systematize the discussion concerning such a revision, we introduce two new terms: surplus levy and surplus manure. The surplus manure is the basis of the surplus levy. The surplus levy not only pertains to phosphate, but also to nitrogen. In our view the surplus levy should be imposed both on the nitrogen surplus and the phosphate surplus of an individual farm. The sum of nitrogen surplus and phosphate surplus is called the nutrient surplus. The nutrient surplus is defined as the difference between the actual amount of nutrients used on land and the environmental standards (as specified for both nutrients in Table IV). For an individual farm the nutrient surplus is determined by means of nutrient accountancy, including the use of chemical fertilizers and all kinds of manure. Unlike the excess levy in the current manure policy, no levy is imposed on transported manure (i.e. transported to farms that need nutrients which otherwise will be bought as fertilizers). Transportation of manure to "deficiency" regions, 
as well as to manure processing factories, in principle offers opportunities for the reduction of a local nutrient surplus, provided that these actions do not cause environmental damage elsewhere.

Calculations show that a level of at least 1.25 guilders per $\mathrm{kg}$ phosphate as well as 1.25 guilders per kg nitrogen is needed to give the surplus levy an allocative function (Hoevenagel and Hoogervorst, 1989). Taking the average composition of manure into account, this surplus levy corresponds to 9.40 guilders per ton of surplus manure. It is not quite possible to compare the level of the proposed surplus levy and the level of the excess levy which is used in the current manure policy, because the basis of the levies differs. As a rough indication it can be assumed that the level of the surplus levy is approximately 10 times higher than that of the excess levy.

The reaction of farmers to the introduction of this surplus levy is expected to vary with the amount of manure they produce. Farmers who produce little or no manure on their own farm, are discouraged from buying manure from other farmers. This is mainly due to the introduction of standards for nitrogen. Farmers who produce substantial or large amounts of manure will be pushed by the surplus levy to reduce their use of chemical fertilizers. Reducing the use of fertilizers means a reduction in production costs for animal feed (roughage) and possibly a (small) reduction in the yield per hectare.

We conclude that the losses of nutrients to the environment will decrease by introducing the surplus levy. Moreover, our calculations demonstrate that the surplus levy will only moderately increase the production costs of intensive livestock holders (see Section 7). Transportation costs for manure remain the largest fraction of total production costs. Thus, the introduction of the surplus levy itself will certainly not result in a spate of bankruptcies among intensive livestock holders, as most farmers' organizations and politicians seem to expect.

\section{Additional Financial Incentives to Decrease Nutrient Losses}

In addition to the surplus levy one might consider imposing a levy on nutrient-rich animal feed. The surplus levy is in principal indifferent to the methods farmers can use to decrease their individual nutrient surplus. The reduction of the nitrogen and phosphorus content in animal feed is a means of abating the pollution at the source instead of at "the end of the intestine". By imposing a feed levy one could express a preference for a source-oriented abatement strategy.

Apart from levies on a nutrient surplus and on nutrient-rich animal feed, subsidies on certain investments can also help to decrease environmental damage. All of these investments should have the common goal of increasing the efficient use of nutrients and, in doing so, decreasing the loss of nutrients to the environment. Here one could think of putting roofs on 
manure storages, using biofilters to filter ammonia from stable air, installing feed equipment to facilitate use of feed with differing nutrient contents at the same time and, finally, using manure injectors which allow subsurface manure application to grassland. Furthermore, a number of farmers, probably those without a successor and those who make a small or even a negative income, could be tempted to stop farming, for example by granting a certain income guarantee by the government until the age of retirement. Such an arrangement can substantially reduce the total production of manure. In particular, those farmers could be tempted who are not motivated to adapt their farm in order to reduce the loss of nutrients, even when the adaptations are substantially subsidized.

\section{Consequences of the Nutrient Policy}

In the preceding sections the main goals and instruments of the proposed nutrient policy have been briefly discussed. Regarding the environmental requirements, it is clear that the nutrient policy is much stricter than the government's manure policy. In response to proposals for a more strict environmental policy in general, politicians, bureaucrats, farmers and their organizations usually claim that a stricter environmental policy will lead to unbearable costs for the government as well as for the agricultural sector. This so-called narrow financial attitude usually receives a disproportionately large share of the attention. Apparently, the government has more of an eye to expenditure on environmental policy (which often is not the same as costs) than to the benefits of environmental policy (which often cannot be quantified in monetary terms).

Anticipating this narrow financial attitude, we calculated the main financial effects of the proposed nutrient policy for the government as well as for the agricultural sector and compared these with the financial impact of the current manure policy. For these calculations we did not have an economic model by which the effects of all measures on economic variables, such as benefits and expenses for the government, farmers' income, consumer prices of intensive livestock products, changes in the balance of payments, etc., can be determined simultaneously. Instead, we calculated the effects for each policy measure separately, also taking second order effects into account, such as adaptations in farming practice to new price ratios of inputs which are changed by the imposition of levies and the creation of subsidies. To calculate the changes in the total amount of manure production resulting from the nutrient policy, as well as the current manure policy, we used a scenario model from the Institute of Environmental Studies (Kuik, 1988). Finally, we calculated the total financial effect for the government as well as the agricultural sector by adding up all the effects of the separate policy measures for both the nutrient policy and the current manure policy. ${ }^{5}$ 
For the government the nutrient policy means higher receipts (the surplus levy, the levy on nutrient-rich animal feed) as well as higher expenditures (several investment subsidies, an arrangement to compensate farmers who voluntarily stop producing manure). We found that executing the nutrient policy will cost the government, until the year 2000, on balance approximately 100 million guilders a year more than is envisioned in the current manure policy. The government outlays for acidification and eutrophication from agriculture in the National Environmental Policy Plan are estimated ${ }^{6}$ to amount to 175 million guilders a year (in 1994) (Ministerie van VROM, 1989, p. 238). With this money only part of the ammonia and phosphate problem is solved, while the nitrate problem remains largely unattacked. With an additional expenditure of 100 million guilders a year the environment could be permanently protected against the excessive use of nitrogen and phosphate in agriculture. In other words, the nutrient policy costs more than the government's manure policy, but is also much more effective in reducing pollution.

In the agricultural sector the nutrient policy will lead to net additional ${ }^{7}$ production costs of approximately 900 million guilders per a year. The government's manure policy will have a roughly similar effect (according to our calculations). Under the nutrient policy the additional costs in the dairy sector are calculated at 544 million guilders per year, mainly due to the construction of manure storage facilities and more expensive concentrated feedstuffs, and taking account of a considerable reduction in the production costs resulting from the diminished use of chemical fertilizers. In the intensive livestock sector (pigs and poultry) the additional costs due to the nutrient policy are calculated at 458 million guilders per year, mainly due to the extension of manure storage capacity, transportation of surplus manure, the surplus levy and more expensive concentrated feedstuffs. On the other hand, the government will provide extra subsidies and payments to the agricultural sector at approximately 120 million guilders per year. The arrangements for subsidies and payments will be provided until 2000, the year in which the final standards for the use of nutrients have to be attained. According to our calculations the additional costs due to the nutrient policy will decrease farmers' income by approximately $6 \%$ on average.

The nutrient policy affects the competitive power of Dutch livestock farmers on European and world markets only in a reasonably moderate way. We estimated the increase in production costs of both the government's manure policy and our proposed nutrient policy. The results are shown in Table V. On balance, the increase in production costs in both policies are of the same order of magnitude. So a strict environmental policy does not necessarily lead to a deterioration in the competitiveness of Dutch agriculture.

The contribution of the agricultural sector to the balance of payments 
Table V. Estimated increase in the production costs of the government's manure policy and the proposed nutrient policy (percentages)

\begin{tabular}{lll}
\hline Product & Government policy & Nutrient policy \\
\hline milk & 5.96 & 5.56 \\
pork & 0.84 & 1.21 \\
piglets & 1.42 & 2.19 \\
eggs & 2.69 & 4.03 \\
poultry meat & 3.38 & 4.68 \\
\hline
\end{tabular}

Source: Hoogervorst et al., 1989, p. 39.

has always been an important issue for the government. The balance of payments, however, is not only affected by the exports of dairy products and pork, but also by the imports of animal feed and raw materials for fertilizer production. Unlike the manure policy, the use of fertilizers is also regulated in the proposed nutrient policy. As a result, the import of phosphorus rock as well as the import of energy (used for the production of nitrogen fertilizers) can be reduced. We calculated that by the year 2000 the use of nitrogen fertilizers could be reduced to $50 \%$ of their use in 1987. Also the use of phosphate fertilizers could decrease to $60 \%$ of the amount used in 1987.

Finally, the nutrient policy will induce an additional and increasing demand for new installations and equipment, like feeding equipment, airtight manure silos, biofilters and manure injectors. The nutrient policy would also lead to a demand for new services, such as manure dispersion and ploughing, as well as the maintenance of manure handling equipment.

\section{Conclusions}

If the alternative nutrient policy were implemented, the most important effects can be summarized as follows:

1. From the year 2000 onwards, the environment will no longer deteriorate as a result of the excessive use of phosphate and nitrogen in agriculture.

2. Farmers will be financially stimulated to use nutrients efficiently.

3. The financial costs of modifications to farming practices will not only be paid by farmers. Both consumers (as taxpaying citizens) and the government will also contribute to the solution of the problem of excessive use of nutrients.

The most important conclusion, however is, that the cost-benefit ratio of 
the proposed nutrient policy is substantially more favorable than that of the current manure policy. The nutrient policy induces negligible additional costs for the agricultural sector and only limited additional costs for the government (100 million guilders per year), while a considerable improvement in the environmental quality will be attained. In contrast, the current manure policy insufficiently reduces the nutrient leakages to the environment at a cost which is only slightly lower than the proposed nutrient policy. The improvement of the social efficiency in the nutrient policy is mainly due to the use of financial policy instruments. In other words, the implementation of financial policy instruments would offer society a promising opportunity to attain considerable improvements in factor allocation, without unacceptable social problems.

\section{Notes}

Manure also contains heavy metals, such as cadmium, copper, mercury, lead and zinc, originating from concentrated feedstuffs. The application of manure to land substantrally contributes to the accumulation of heavy metals in soils and food. In this paper we leave out this specific environmental problem, since we focus on the environmental effects of nutrient leakages from manure application.

2 This is equivalent to the standard for drinking water set by the WHO. Leaching of nitrate not only threatens the quality of drinking water, it also disturbs and, in the long run, destroys oligotrophic ecosystems by eutrophication. The standard of $25 \mathrm{mg}$ nitrate per liter seems adequate to protect ordinary ecosystems, but oligotrofic ecosystems require much tighter standards.

3 This integration strategy is not applicable to intensive livestock farms with little or no land. With respect to these farms we propose a special ammonia policy based on the allotment of marketable ammonia emission rights to each farm. Calculations show that in 1990 these farms will emit $45 \mathrm{kton}$ ammonia ( $18 \%$ of the total emissions of ammonia from agriculture). By 2000 these emissions have to be decreased to $5.7 \mathrm{kton}$ per year. As compared with 1980 this means an emission reduction of $90 \%$ in afforested areas and an emission reduction of $70 \%$ in all other areas. These reductions can be attained by yearly reduction of the emission rights.

4 Above the final standard of $125 \mathrm{~kg}$ phosphate per ha a levy has to be pard of 25 cents per $\mathrm{kg}$ per ha. Every kilogram phosphate over $200 \mathrm{~kg} \mathrm{P} \mathrm{O}_{5}$ per ha is surcharged by 50 cents. A levy of 25 to 50 cents per $\mathrm{kg}$ phosphate corresponds to 63 cents to 1.25 guilders per ton of (average) manure.

5 The calculations are extensively described in Hoogervorst et al. (1989, pp. 137-169), including the assumptions that are made.

6 This amount seems to be underestimated since outlays for research and enforcement are not included. We have estimated that enforcement outlays amount to 7 million guilders per year. Outlays for research are expected to be 63 million guilders per year (Mestaktieprogramma) and should be covered by the manure excess levy, estimated to reach 40 million (NMP) to 46 million (our calculation) guilders per year.

7 These costs are additional when compared to the situation without any environmental policy. 


\section{References}

Biezen, J, van and N. J. P. Hoogervorst (1989), Stikstofgebruik in de landbouw in vergelijking met advlezen, LUW-Werkgroep Landbouwpolitiek, Wageningen.

CBS (Centraal Bureau voor de Statistiek) (1986), Produktie van dierlijke mest 1984, SDU, Den Haag.

CBS (Centraal Bureau voor de Statistiek) (1991), Maandstatistiek voor de landbouw, jaargang 39, januari 1991, SDU, Den Haag.

Dietz, F. J. and N. J. P. Hoogervorst (1989), 'Naar een effectief en efficient meststoffenbeleid', $E S B, 512-515$.

Duijvenbooden, W. van (ed.) (1989), De kwaliteit van het grondwater in Nederland, RIVM, Rapportnr. 728820001, Bilthoven.

Erisman, J. W. and G. J. Heij (1991), 'Concentration and deposition of acidifying compounds', in G. J. Heij and T. Schneider (eds.), Final Report Second Phase Dutch Priority Programme on Acidlfication, RIVM, report no. 200-09, Bilthoven, pp. 51-96.

Heij, G. J. and T. Schneider (eds.) (1991). Final Report Second Phase Dutch Priority Programme on Acidification, RIVM, report no. 200-09, Bilthoven.

Hoevenagel, R. and N. J. P. Hoogervorst (1989), 'Nutriëntenarm veevoer', in N. J. P. Hoogervorst et al., Naar een duurzaam gebruik van meststoffen, LMO, Utrecht, Voorstudie 1.

Hoogervorst, N. J. P. et al. (1989), Naar een duurzaam gebruik van meststoffen; aanzetten tot een alternatief meststoffenbeleid, $\mathrm{LMO}$, Utrecht.

Kolenbrander, G. J. (1981), 'Leaching of Nitrogen in Agriculture', in J. C. Brogan (ed.), Nitrogen Losses and Surface Run-off, Brussels-Luxembourg, ECSC, EEC, EAEC.

Kuik, O. J. (1988), Het IVM-mestmodel, Instituut voor Milieuvraagstukken, Amsterdam.

Langeweg, F. (ed.) (1988), Zorgen voor morgen (Concern for Tomorrow), RIVM-rapport, Samson, Alphen a/d Rijn.

LNV (Ministerie van Landbouw, Natuurbeheer en Visserij) (1990), 'De kwaliteit van het Nederlandse bos 8', Verslag van de landelijke inventarisatie 1990, Directie Bos- en Landschapsbouw, rapport no. 1990-19.

Meyer, B. J. M. and P. F. Lalkens (1988), 'Economische analyse van de bedrijfssystemen op het proefbedrijf OBS', in Themadag geintegreêrde bedrijfssystemen, PAGV, Lelystad.

Ministerie van Landbouw en Visserij (1989), Structuurnota landbouw, SDU, Den Haag.

Ministerie van VROM (1989), Nationaal milieubeleids plan (National Environmental Policy Plan 1990-1994), SDU, Den Haag.

Ministerie van VROM (1990), Nationaal milieubelelds plan plus, SDU, Den Haag.

Neeteson, J. J. (1989), 'Evaluation of the performance of three advisory methods for nitrogen fertilization of sugar beet and potatoes', in Neth. J. of Agricultural Science 37, 143-155.

Stee, A. P. J. M. M. van der (chairman) (1989), Om schone zakelijkheid; Perspectieven voor de agrartsche sector in Nederland, Landbouwschap, Den Haag.

Wijnands, J., H. Luesink, and M. van der Veen (1988), 'Impacts of the manure laws in the Netherlands', TSL, no. 4.

Wit, C. T. de (1988), 'Problemen van duurzaamheid in de landbouw', in M. Groen (ed.), Naar een duurzaam Nederland, SDU, Den Haag. 